\title{
JUURNAL.RU
}

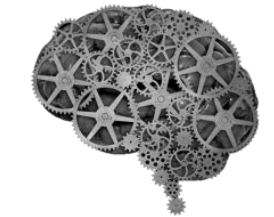

COMPANY GROUP "INTELLEKT"

Юрина А.В. Пензенский Государственный Университет Пенза, Россия

doi: 10.18411/lj2016-5-4-12

\section{Уполномоченный по правам ребенка как независимый государственно- правовой институт защиты прав ребенка в Российской Федерации}

Дети являются будущем государства, но к сожалению, практика показывает, что в современном мире от различных негативных социальных явлений, в первую очередь, страдает ребенок - от социальной несправедливости, от бедности семьи, неразумности взрослых в решении семейных конфликтов, а порой и от жестокого обращения, насилия со стороны взрослых. Поэтому неслучайно во всем мире проблемам детства уделяется особое внимание. В международной практике сложился дополнительный независимый механизм, позволяющий обеспечить целенаправленную и приоритетную защиту прав как каждого конкретного ребенка, так и детей в целом. Речь идет об институте Уполномоченного по правам ребенка, так называемом «детском омбудсмане».

B Российской Федерации вопросы детства и защиты прав ребенка являются приоритетными в политике государства. Ратифицировав Конвенцию $\mathrm{OOH}$ «O правах ребенка», наша страна приняла на себя обязательства по созданию достойных условий жизни и полноценного развития каждого ребенка. Создание специализированной системы защиты прав детей, включая дальнейшее развитие института Уполномоченных по правам ребенка, явилось одной из задач концепции демографической политики Российской Федерации на период до 2025 года. Последующим шагом по совершенствованию защиты прав и законных интересов ребенка в Российской Федерации стал Указ Президента 
Российской Федерации в 2009 году о введении должности Уполномоченного при Президенте Российской Федерации по правам ребенка.

Впервые в мире Уполномоченный по правам ребенка появился в начале 20 века в Швеции, в дальнейшем такие должности были введены в Австралии, Австрии, Канаде, Ирландии, Румынии и других странах. В Российской Федерации в 1998 году впервые Уполномоченные по правам ребенка появились в Волгоградской области, Калужской области, а также в городах Санкт- Петербурге, Екатеринбурге и Новгороде. Основная функция Уполномоченного по правам ребенка при президенте Российской Федерации служить гарантом соблюдения прав и свобод ребенка. Институт Уполномоченных по правам ребенка стал важным звеном в государственной системе обеспечения прав и законных интересов детей, заняв в сложившейся системе государственных органов способствующих защите прав детей свое особое место, но в то же время тесно связанный с ними.

Ребенок, обращая внимание на возраст и связанные с ним особенности психики, физического и интеллектуального формирования, а также, если не забывать о том, что он является ограниченно дееспособным, - не может в большинстве случаев осуществлять самостоятельную защиту своих прав и законных интересов. От их лица уполномочены действовать законные представители (родители, опекуны, директора детских учреждений и прочие). В случае если права ребенка нарушены самими законными представителями, а также в случае, когда они отказываются отстаивать нарушенные права ребенка, тот останется беззащитным. Поэтому в Российской Федерации были разработаны и внедрены меры по учреждению на законном основании должности - Уполномоченного по правам ребёнка

В соответствии с Указом Президента Российской Федерации от 01.09.2009 N 986 "Об Уполномоченном при Президенте Российской Федерации по правам ребенка" Уполномоченный по правам ребенка "вправе проводить самостоятельно или совместно с уполномоченными государственными органами 
и должностными лицами проверку деятельности федеральных органов исполнительной власти, органов государственной власти субъектов Российской Федерации, а также должностных лиц, получать от них соответствующие разъяснения; направлять в федеральные органы исполнительной власти, органы государственной власти субъектов Российской Федерации, органы местного самоуправления и должностным лицам, в решениях или действиях (бездействии) которых он усматривает нарушение прав и интересов ребенка, свое заключение, содержащее рекомендации относительно возможных и необходимых мер восстановления указанных прав и интересов; привлекать в установленном порядке для осуществления экспертных и научно-аналитических работ, касающихся защиты прав ребенка, научные и иные организации, а также ученых и специалистов, в том числе на договорной основе". Кроме того, Уполномоченный при Президенте Российской Федерации по правам ребенка наделен иными полномочиями, предусмотренными действующим законодательством.

Заняв свое место в системе государственных органов, данный институт стал инструментом независимого государственного контроля за соблюдением прав и интересов ребенка, эффективным механизмом комплексной защиты прав и законных интересов как отдельных детей, так и целых групп.

На протяжении последних десятилетий в мировой практике вырабатывается дополнительный механизм, позволяющий обеспечить целенаправленную и приоритетную защиту прав ребенка: как каждого конкретного ребенка при нарушении его прав, так и детей в целом. Таким механизмом является институт Уполномоченного по правам ребенка. По информации ЮНИСЕФ, во многих странах службы Уполномоченных по правам ребенка на национальном и региональном уровнях выполняют функции независимого механизма обеспечения прав ребенка.

Сегодня Уполномоченный по правам ребенка в Российской Федерации, а также в ее субъектах своей деятельностью дополняет уже существующие формы 
и средства защиты прав ребенка, не подменяя традиционные для Российской Федерации структуры, в компетенции которых находятся те или иные компоненты обеспечения прав и законных интересов ребенка (органы образования, здравоохранения, социальной защиты, опеки и попечительства, комиссии по делам несовершеннолетних, прокуратура).

Основными задачами Уполномоченного по правам ребенка, закрепленными в регламентирующих их деятельность документах, являются:

- - обеспечение гарантий и законных интересов, прав и свобод ребенка, развитие и дополнение существующих форм и средств защиты прав ребенка во взаимодействии с органами государственной власти и органами местного самоуправления, в компетенцию которых входит защита прав и законных интересов ребенка;

- - всемерное содействие восстановлению нарушенных прав ребенка;

- - анализ состояния дел по соблюдению прав ребенка, и подготовка предложений по совершенствованию законодательства.

Уполномоченные для выполнения стоящих перед ними задач имеют право:

- - посещать государственные органы и органы местного самоуправления, учреждения, организации и предприятия независимо от форм собственности (особенно важно, что Уполномоченные обладают правом беспрепятственного посещения детских интернатных учреждений);

- - проводить самостоятельно или с участием государственных и муниципальных органов проверки обстоятельств, связанных с нарушением прав ребенка;

- - направлять государственным органам, органам местного самоуправления и их должностным лицам предложения и рекомендации, относящиеся к обеспечению прав ребенка и совершенствованию процедур, затрагивающих права ребенка; 
- - при выявленных нарушениях прав детей или конкретного ребенка обратиться в суд, в компетентные органы с просьбой о возбуждении дисциплинарного или административного производства в отношении должностных лиц, в действиях которых усматриваются нарушения прав ребенка;

- - готовить предложения о внесении изменений в действующее законодательство по вопросам, затрагивающим права ребенка;

- - привлекать к совместной работе квалифицированных специалистов и создавать экспертные группы, советы по правам ребенка из числа ученых и специалистов, работающих с детьми, привлекать к сотрудничеству неправительственные организации.

В своей деятельности Уполномоченный по правам ребенка тесно сотрудничает со всеми структурами и органами государственной власти, в чью компетенцию входит обеспечение прав ребенка, а также с общественными, в том числе правозащитными, организациями. Как правило, при Уполномоченных по правам ребенка действуют общественные приемные, где работают квалифицированные юристы.

В отличие от других существующих сегодня в Российской Федерации государственных органов, в чьей компетенции находится защита прав детей, главным назначением института Уполномоченного по правам ребенка является:

- - осуществление независимого контроля со стороны общества за деятельностью государственных органов, органов местного самоуправления по обеспечению прав детей, детских учреждений в части обеспечения прав детей;

- - защита ребенка, чьи права нарушены органами государственной власти, органами местного самоуправления, их должностными лицами, работниками учреждений;

- - содействие восстановлению нарушенных прав ребенка. 
В отличие от органов прокуратуры, к компетенции которых отнесен широкий круг вопросов, в том числе надзор за исполнением законодательства, координация деятельности правоохранительных органов и многое другое, деятельность Уполномоченного по правам ребенка сосредоточена исключительно на защите прав и законных интересов одной группы населения детей. Как показывает практика, процедура обращения в органы прокуратуры не позволяет ребенку это осуществить, тогда как в основе работы Уполномоченного по правам ребенка лежит максимальная доступность для каждого ребенка - такая, чтобы в случае необходимости он мог самостоятельно обратиться к Уполномоченному за помощью. В силу этого Уполномоченный может более глубоко и эффективно заниматься вопросами защиты прав ребенка в пределах своей компетенции, прежде всего своевременным выявлением факта нарушения прав ребенка.

Если органы опеки и попечительства занимаются вопросами защиты прав детей-сирот, детей, оставшихся без попечения родителей, вопросами соблюдения прав детей в семье или в учреждениях для детей, оставшихся без попечения родителей, то есть преимущественно неблагоприятными для ребенка последствиями внутрисемейных отношений, то в поле деятельности Уполномоченного по правам ребенка находится защита прав и законных интересов ребенка во взаимоотношениях со всеми социальными институтами и организациями.

Спектр проблем положения детей, которыми занимается Уполномоченный по правам ребенка в Российской Федерации, шире, чем у комиссии, и, кроме того, он занимается ими лично и на постоянной основе, в том числе и с помощью своего аппарата. По следующим причинам Уполномоченный по правам человека в Российской Федерации не может столь же эффективно, как это делает Уполномоченный по правам ребенка в Российской Федерации, осуществлять функции защиты прав ребенка. Компетенция Уполномоченного по правам человека в Российской Федерации в основном определена как 
рассмотрение жалоб, а процедура их подачи исключает возможность подачи жалобы ребенком (необходимо обращаться письменно, жалоба должна содержать изложение существа решений или действий (бездействия), нарушивших или нарушающих, по мнению заявителя, его права и свободы, и сопровождаться копиями решений, принятых по его жалобе, рассмотренной в судебном или административном порядке). Учитывая, что ребенок в силу возраста не способен самостоятельно использовать правовые средства защиты, а также масштабы территории Российской Федерации и то, что нарушение прав ребенка происходит непосредственно по месту их жительства (пребывания), возможности Уполномоченного по правам человека в Российской Федерации для оперативного реагирования на нарушения прав детей крайне малы.

Эффективность работы Уполномоченного по правам ребенка в Российской Федерации обусловлена тем, что он лично участвует в содействии восстановлению прав как отдельного ребенка, так и групп детей, чьи права нарушаются, непосредственно по месту жительства (пребывания) ребенка. Лицо, избираемое (или назначаемое) на должность Уполномоченного по правам ребенка, обладает общественным авторитетом. Сама процедура назначения на эту должность предполагает, что Уполномоченный по правам ребенка - лицо незаурядное, обладающее помимо высоких профессиональных и необходимыми личными качествами. Принципиальным отличием деятельности Уполномоченного по правам ребенка от всех остальных субъектов защиты прав ребенка является то, что каждый из них с первых дней своей деятельности активно осуществляет правовое просвещение, прежде всего самих детей, налаживает линии связи с детьми, посещает детские учреждения, разъясняя детям в доступной форме их права и обязанности, возможности их защиты, каким образом и куда они могут обратиться за помощью в конкретных обстоятельствах.

Наряду с защитой прав конкретного ребенка Уполномоченный по правам ребенка содействует защите прав детей в целом. С этой целью Уполномоченный 
по правам ребенка ведет мониторинг соблюдения прав ребенка, проводит независимый вневедомственный анализ и оценку состояния дел по обеспечению прав и законных интересов детей, посещают детские учреждения; особое внимание придается проверке соблюдения прав ребенка, находящегося в интернатных учреждениях. На основе полученной информации Уполномоченным по правам ребенка вносятся предложения органам государственной власти по улучшению положения ребенка, реализации его прав в соответствии с действующим законодательством, а также предложения субъектам Российской Федерации использовать право законодательной инициативы по совершенствованию законодательства в интересах ребенка. Кроме того, осуществляется правовая экспертиза законопроектов, затрагивающих интересы ребенка.

Подготовка ежегодных докладов о деятельности, а также специальных докладов, доведение их до сведения должностных лиц и широкой общественности дает возможность Уполномоченному по правам ребенка изложить свое видение ситуации с обеспечением прав ребенка как в целом по стране, так и в отдельных сферах жизни общества, является мощным рычагом воздействия на общественное мнение.

Основная масса дел, связанных с восстановлением нарушенных прав ребенка, рассматривается на основе поступающих по почте письменных заявлений обращений и жалоб граждан на решения или действия (бездействие) государственных органов, органов местного самоуправления, должностных лиц, государственных служащих.

Уполномоченный по правам ребенка оказывает консультационную помощь гражданам, желающим реализовать свое конституционное право обратиться в международные органы по правам человека (Европейский Суд, Комитет ООН по правам человека и другие).

Одним из главных способов реализации Уполномоченным по правам ребенка в Российской Федерации своих контрольных функций является процесс 
рассмотрения жалоб граждан Российской Федерации, а также обращений иностранных граждан и лиц без гражданства.

Подобное правило существует в Новой Зеландии, Польше, Швеции и других странах.

Законодатель устанавливает некоторые изъятия из сферы компетенции Уполномоченного по правам ребенка, в соответствии с которыми Уполномоченный по правам ребенка не рассматривает жалобы на решения Совета Федерации и Государственной Думы Федерального Собрания Российской Федерации, а также законодательных (представительных) органов субъектов Российской Федерации.

Ребенок может обращаться со своей жалобой, как к уполномоченному по правам ребенка субъекта Российской Федерации, так и к Уполномоченному по правам ребенка на федеральном уровне. Если ребенок в начале обратился со своей жалобой к Уполномоченному по правам ребенка в субъекте Российской Федерации - это не является причиной для отказа в принятии жалобы по аналогичной проблеме Уполномоченным по правам ребенка в Российской Федерации.

Активная деятельность Уполномоченного по правам ребенка в Российской Федерации на федеральном и региональном уровнях получила одобрение международного сообщества и высших органов государственной власти Российской Федерации, заслужила доверие со стороны населения, особенно родителей и детей, позволила в значительной мере переориентировать усилия региональных и местных органов власти в направлении приоритетной защиты ребенка.

Положительным итогом стало принятие региональных законов, целевых программ, региональных стандартов по вопросам охраны прав и интересов детей, что позволило добиться, в частности, положительных результатов решении проблем семейного устройства детей-сирот и детей, оставшихся без попечения родителей, сокращению сети детских сиротских учреждений, 
оказанию действенной помощи семьям с несовершеннолетними детьми, увеличению выделяемых на их нужды пособий и иных выплат.

Но с другой стороны развитие института Уполномоченного по правам ребенка в Российской Федерации на федеральном уровне и на уровне субъектов Российской Федерации и повышение дальнейшего развития его деятельности по содействию защиты прав ребенка ограничивается некоторыми проблемами, например, отсутствие у Уполномоченного по правам ребенка в Российской Федерации права законодательной инициативы, a также ограниченная возможность обращения в Конституционный Суд Российской Федерации.

Обобщая все выше сказанное, следует отметить, что содержание деятельности Уполномоченного по правам ребенка в Российской Федерации является признаком стремления государства и общества способствовать воплощению принципов Конвенции ООН «о правах ребенка», осуществлять деятельность по обеспечению их прав и законных интересов. Однако, существуют так же определенные проблемы, недостатки, объективного и субъективного характера, которые снижают эффективность деятельности Уполномоченного по правам ребенка в Российской Федерации, поэтому важно необходимо принимать оперативно меры по устранению этих недостатков и проблем, а также совершенствовать законодательство Российской Федерации, касающееся сфер деятельности защиты и охраны прав ребенка, в частности Уполномоченного по правам ребенка.

Взаимодействие с Комитетом ООН по правам ребёнка является ключевым для Российского Уполномоченного по правам ребёнка. Оно заключается в подготовке Периодических докладов о выполнении Российской Федерацией положений Конвенции о правах ребёнка и их направлению на рассмотрение в Комитет ООН по правам ребёнка, который впоследствии формулирует Заключительные замечания по этим докладам, необходимые для осуществления положений Конвенции на территории Российской Федерации. 
Уполномоченный должен тщательно изучать данные замечания, содержащие важные рекомендации, постоянно ссылаться на них в целях информирования и просвещения государственных органов и населения, а также повышения своего статуса путём корректировки, а в дальнейшем и реформы законодательства о защите ребенка. Кроме того, представляется необходимым для омбудсмена посещать заседания Комитета ООН по правам ребёнка, участвовать в правозащитных диалогах с целью повышения легитимности института Уполномоченного по правам ребёнка. Значимость участия Уполномоченного в составлении специальных докладов государства, предназначенных для изучения конвенционными органами, а также необходимость работы Уполномоченного по правам ребенка в составе делегации страны, направляемой в конвенционный орган для обсуждения упомянутых докладов.

Таким образом можно с уверенностью говорить о необходимости в ближайшей перспективе подписать и ратифицировать Факультативный протокол к Конвенции о правах ребенка, касающийся процедуры сообщений. Это позволит каждому российскому ребёнку в случае нарушения его прав обращаться за помощью в Комитет ООН. При этом представляется, что именно Уполномоченный станет посредником между ребёнком и Комитетом. Думается, что осуществление контрольных мероприятий Комитетом ООН по правам ребёнка в отношении государственных органов, компетенцией которых является защита ребенка, позволит обеспечить более действенное функционирование государственного управления в восстановлении нарушенных прав, свобод и законных интересов ребёнка. 


\section{Литература:}

1. 1.Батова О.С. «Пути устранения противоречий гражданского процессуального и семейного законодательства при рассмотрении споров, связанных с воспитанием детей» Журнал российского права. 2010. №6

2. "Конвенция о правах ребенка" (одобрена Генеральной Ассамблеей ООН 20.11.1989) (вступила в силу для СССР 15.09.1990)

3. 3.Смирнов С.Л. «Становление и развитие института Уполномоченного по правам ребенка в Российской Федерации и ее субъектах» Москва 2010 г.

4. 4.Указ Президента Российской Федерации от 01.09.2009 N 986 "Об Уполномоченном при Президенте Российской Федерации по правам ребенка"

5. 5.Хаманева Н.Ю. «Уполномоченный по правам ребенка - защитник прав ребенка» Институт государства и права РАН. Серия Новое в юридической науке и практике Москва 2011 г.

6. Указ Президента Российской Федерации от 01.09.2009 N 986 "Об Уполномоченном при Президенте Российской Федерации по правам ребенка" 